Vol. 3. No. 2 Juli 2014

\title{
HUBUNGAN ANTARA PERSEPSI SISWA TENTANG PEMANFAATAN MEDIA PEMBELAJARAN KIT IPA DAN MOTIVASI BELAJAR DENGAN HASIL BELAJAR IPA
}

\author{
Didin Badrudin ${ }^{1}$, Yanuardi ${ }^{2}$, Sigit Wibowo ${ }^{3}$ \\ Program Studi Teknologi Pendidikan Pascasarjana UIKA Bogor \\ Jl. KH. Sholeh Iskandar Km. 2 Kd. Badak, Bogor \\ (didinbadrudin14@yahoo.co.id)
}

\begin{abstract}
Abstrak: Tujuan penelitian ini adalah untuk menguji hubungan antara persepsi siswa tentang pemanfaatan media pembelajaran KIT IPA dan motivasi belajar dengan hasil belajar IPA di Sekolah Dasar Gugus IV Gunung Sari Kecamatan Pamijahan-Bogor, baik secara sendiri-sendiri maupun bersama-sama. Populasi penelitian ini adalah seluruh siswa kelas VI Sekolah Dasar yang ada di Gugus IV Gunung Sari Kecamatan Pamijahan-Bogor yang berjumlah 193 orang. Secara keseluruhan jumlah sampel yang diambil sebanyak 130 orang siswa. Terdapat dua variabel bebas, yaitu Persepsi siswa tentang media pembelajaran KIT IPA $\left(X_{1}\right)$ dan Motivasi belajar siswa $\left(X_{2}\right)$. Data kedua variabel tersebut dikumpulkan dengan menggunakan instrumen non tes dalam bentuk kuesioner (angket). Sedangkan untuk variabel terikat yaitu hasil belajar IPA, data dikumpulkan dengan menggunakan instrumen tes dalam bentuk soal objektif pilihan ganda. Uji validitas instrumen untuk variabel $X_{1}$ dan $X_{2}$ menggunakan rumus korelasi Product Moment. Uji Reliabilitasnya menggunakan rumus Alpha Cronbach. Hasil uji reliabilitas kedua variabel diperoleh nilai reliabilitas sebesar 0,945 untuk variabel $X_{1}$ dan 0,922 untuk variabel $X_{2}$. Sedangkan uji validitas instrumen tes dilakukan dengan menggunakan rumus korelasi Point Biserial. Uji reliabilitas instrumen tes menggunakan rumus KR-20, dengan hasil sebesar 0,947. Dari hasil analisis data disimpulkan sebagai berikut: (1) terdapat hubungan positif antara persepsi siswa tentang pemanfaatan media pembelajaran KIT IPA $\left(X_{1}\right)$ dengan hasil belajar $(Y)$ sebesar 0,638. Besarnya kontribusi persepsi siswa tentang pemanfaatan media pembelajaran terhadap hasil belajar IPA yakni sebesar 40,7\%. (2) terdapat hubungan positif antara motivasi belajar dengan hasil belajar IPA sebesar 0,614. Besarnya kontribusi motivasi belajar terhadap hasil belajar IPA yakni sebesar $37,7 \%$. (3) korelasi berganda antara kedua variabel bebas dengan variabel terikat tersebut, adalah sebesar 0,736, sehingga kontribusi kedua variabel bebas terhadap variabel terikat $\left(X_{1}\right.$ dan $X_{2}$ terhadap $Y$ ) adalah sebesar $54,1 \%$.
\end{abstract}

Kata Kunci: Media Pembelajaran KIT IPA, Motivasi Belajar, Hasil Belajar

Abstract : The purpose of this study was to examine the relationship between students perceptions about the use instructional media KIT IPA and motivation to learn science with science learning outcomes in Cluster IV Elementary School District of Gunung Sari Pamijahan-Bogor, either individuality or jointly. The study population was all students in the sixth grade of elementary school in Cluster IV Gunung Sari-Bogor subdistrict Pamijahan totaling 193 people. Overall the number of samples taken 130 students. There are two independent variables, namely the perception of students about learning media KIT IPA (X1) and the Students motivation (X2). The data collected by these two variables using non-test instruments in the form of a questionnaire. As for the dependent variable is the science learning outcomes, the data collected using test instruments in the form of multiple choice objective questions. Test the validity of the instrument for the variables X1 and X2 using Product Moment Correlation formula. Reliability test using Cronbach alpha formula. Reliability test results obtained by the two variables reliability value of 0.945 to 0.922 for the variables $X 1$ and X2. While the validity of the test instrument test performed using Point biserial correlation formula. Test instrument reliability test using the KR-20 formula, with the yield at 0.947. From the analysis of the data summarized as follows: (1) there is a positive relationship between students perceptions about the use of instructional media KIT IPA (X1) with learning outcomes $(Y)$ equal to 0.638 . The contribution of students perceptions about the use of instructional media on learning outcomes which amounted to $40.7 \%$ IPA. (2) there is a positive relationship between learning motivation and learning outcomes IPA 
at 0.614 . The contribution of motivation toward science learning outcomes which amounted to $37.7 \%$.

(3) Correlation between the two independent variables with the dependent variable, is equal to 0.736 , so that the contribution of the two independent variables on the dependent variable ( $X 1$ and $X 2$ to $Y$ ) is equal to $54.1 \%$.

\section{Keyword: KIT IPA, Learning Motivation, Learning Outcomes}

\section{PENDAHULUAN}

\subsection{Latar Belakang}

Hasil belajar yang dicapai seorang siswa, merupakan hal yang paling penting dalam proses pembelajaran. Hasil belajar yang telah dicapai siswa tersebut nantinya akan digunakan untuk mengukur sejauh mana proses pembelajaran di suatu sekolah telah berlangsung. Hasil belajar seorang siswa didukung oleh beberapa faktor, baik faktor yang berasal dari dalam maupun luar. Semuanya tentu berpengaruh tentang hasil atau prestasi belajar siswa yang diharapkan. Ada banyak faktor yang mempengaruhi tinggi rendahnya hasil belajar siswa. Diantaranya adalah motivasi belajar siswa dan disiplin belajar siswa. Sesungguhnya, beberapa faktor-faktor tersebut saling bertautan dalam sebuah proses pembelajaran

Motivasi sebagai pendorong seseorang untuk melakukan sesuatu berarti bahwa motivasi memberi daya atau kekuatan guna mencapai tujuan yang diinginkan kemudian memberi arah yang jelas tentang kegiatan yang akan dilakukan. Hal tersebut mengidikasikan seluruh kegiatan yang timbul oleh motivasi terjadi tidak secara kebetulan akan tetapi kegiatan yang sifatnya selektif, terarah dan memiliki tujuan yang jelas. Namun sebagaimana diketahui motivasi juga mengalami pasang surut tentang diri seseorang sehingga diperlukan upaya-upaya yang dapat terus menerus menjaga komitmen motivasi yang sudah tertanam dengan baik .

Pada awal abad ke 21 pemanfaatan IImu Pengetahuan Alam dan Matematika berkembang sangat pesat. Kemajuan dan perkembangan suatu bangsa dan setiap manusia tergantung pada pendidikan yang berperan sentral dalam pemanfaatan ilmu pengetahuan alam serta pengembangan selanjutnya. Perkembangan sains dan pergulatan sosial diera saat ini melahirkan kemajuan dan perkembangan keilmuan dan metode-metode pemecahan persoalan yang dihadapi dalam kehidupan walaupun tidak terlepas dari dampak-dampak negatif yang mengikutinya menjadi konsekuensi logis dari sebuah perkembangan. Guru sebagai pendidik dituntut untuk selalu mengikuti perkembangan ilmu pengetahuan, sehingga ilmu yang diajarkan akan selalu menarik bagi peserta didiknya dan tidak tertinggal.

Reformasi sistem pendidikan yang ada mengakibatkan pendekatan-pendekatan komprehensif yang disesuaikan dengan budaya dan nilai-nilai yang dianut masyarakatnya. Contoh sukses dari sebuah pendekatan menyeluruh dalam hal reformasi pembelajaran IPA dapat dijumpai di Indonesia. Pendekatan ini disebut (Science Education Quality Improvement Project) SEQIP, yang merupakan kerja sama bilateral antara pemerintah Indonesia dan Jerman.

Pendekatan pembaruan ini mengaplikasikan strategi multilevel dengan sejumlah intervensi yang dilakukan secara simultan di tingkat sekolah dan lingkungan sekolah. Kegiatan-kegiatan utama mencakup pelatihan bagi pihak-pihak terkait pada setiap tingkatan dalam sistem pendidikan dasar serta penyediaan peralatan eksperimen, buku panduan, dan buku pelajaran. Implementasi proyek ini dilaksanakan dalam skala besar dan melibatkan sekitar 33.000 sekolah di 17 provinsi di Indonesia. Sistem pengawasan ekstensif dikembangkan untuk mengukur hasil-hasil pelatihan pada tingkatan yang berbeda-beda dengan tujuan untuk menentukan pemanfaatan materi-materi yang tersedia, menelusuri perubahan dalam metodologi pembelajaran dan yang terpenting untuk mengukur pencapaian belajar para siswa. Inovasi yang diperkenalkan dalam proses pembelajaran ditindaklanjuti dalam sebuah sistem evaluasi pencapaian yang lebih menekankan pada pemahaman daripada 
pengetahuan faktual. Skema pengamatan proses pembelajaran di kelas diperkenalkan untuk membuktikan besarnya inovasi di kelas.

Implementasi pendekatan pembaruan ini menghasilkan perubahan mendasar dalam pembelajaran IPA, yaitu dari pendekatan tradisional yang berfokus pada guru menjadi pendekatan berfokus pada siswa dan berorientasi pada aktifitas. Untuk menjamin kesinambungan perubahan dan peningkatan yang telah dicapai, maka dikembangkan progam pelatihan untuk institusi-institusi pelatihan guru baik pre-service. Selain itu, Sistem Informasi Manajemen Pendidikan (Education Management Information System /Emis) dibentuk pada tingkat kabupaten.

SEQIP, melalui pemanfaatan perangkat KIT IPA merupakan pendekatan pembelajaran yang ditujukan untuk perbaikan pembelajaran IPA di sekolah dasar. Sejumlah komponen dikembangkan dengan berfokus pada penerapan konsep (learning by doing). Metode pembelajaran menekankan partisipasi aktif siswa di kelas dari pada pendekatan didaktis dimana para siswa hanya menerima informasi secara pasif. Dengan cara ini para siswa mempelajari konsep-konsep dasar ilmu pengetahuan alam secara lebih aktif melalui pengalaman pribadi. Para siswa akan belajar untuk mempercayai kemampuan sendiri untuk mengenali dan menjelaskan dampak dan fenomena alam bila dibimbing untuk memformulasikan dan menguji hipotesa serta meningkatkan ketrampilan dalam mengemukakan pendapat pribadi.

Gugus IV Gunung Sari merupakan salah satu dari sekian ribu lembaga pendidikan formal yang ada di Indonesia. Gugus IV Gunung Sari bertujuan mengantarkan anak didiknya untuk berprestasi gemilang dan menjadi lulusan yang berkualitas dengan selalu meningkatkan prestasi peserta didiknya dari tahun ke tahun. Adapun yang dilakukan di Gugus IV Gunung Sari dalam rangka mewujudkan tujuannya diantaranya adalah dengan menciptakan suasana pembelajaran yang kondusif, nyaman dan menyenangkan.Khusus untuk pelajaran IPA di Gugus IV Gunung Sari, kebanyakan siswa beranggapan bahwa pelajaran IPA adalah pelajaran yang sulit sehingga siswa malas untuk belajar. Selain itu yang menjadi hambatan dalam meningkatkan kualitas proses pembelajaran di Gugus IV Gunung Sari adalah kurangnya referensi buku paket sebagai buku pegangan siswa dari setiap mata pelajaran yang ada, kurangnya sikap disiplin siswa dalam mengikuti proses pembelajaran, dan sikap "nrimo" dari sebagian siswa serta minimnya peralatan praktek IPA, membuat siswa di Gugus IV Gunung Sari menjadi malas belajar.

Dari paparan latar belakang, diperkirakan bahwa pemanfaatan media pembelajaran KIT IPA dan motivasi belajar mempunyai hubungan dengan hasil belajar IPA. Atas dasar itulah penulis bermaksud untuk melakukan penelitian dengan judul: Hubungan antara Persepsi Siswa tentang Pemanfaatan Media Pembelajaran KIT IPA dan Motivasi Belajar dengan Hasil Belajar IPA

\subsection{Rumusan Masalah}

Berdasarkan latar belakang masalah, maka rumusan masalah penelitian adalah:

1. Apakah terdapat hubungan antara persepsi siswa tentang pemanfaatan media pembelajaran KIT IPA dengan hasil belajar IPA siswa Sekolah Dasar di Gugus IV Gunung Sari Kecamatan Pamijahan-Bogor?

2. Apakah terdapat hubungan antara motivasi belajar siswa dengan hasil belajar IPA siswa Sekolah Dasar di Gugus IV Gunung Sari Kecamatan Pamijahan-Bogor?

3. Apakah terdapat hubungan antara persepsi siswa tentang pemanfaatan media pembelajaran KIT IPA dan motivasi belajar secara bersama-sama dengan hasil belajar IPA siswa Sekolah Dasar di Gugus IV Gunung Sari Kecamatan Pamijahan-Bogor?

\subsection{Tujuan Penelitian}

Tujuan yang ingin dicapai dari kegiatan penelitian ini antara lain untuk menguji apakah:

1. Terdapat hubungan yang positif antara persepsi siswa tentang pemanfaatan media pembelajaran KIT IPA dengan 
hasil belajar IPA para siswa Sekolah Dasar di Gugus IV Gunung Sari Kecamatan Pamijahan-Bogor

2. Terdapat hubungan yang positif antara motivasi belajar dengan hasil belajar IPA para siswa Sekolah Dasar di Gugus IV Gunung Sari Kecamatan PamijahanBogor

3. Terdapat hubungan yang positif antara persepsi siswa tentang pemanfaatan media pembelajaran KIT IPA dan motivasi belajar secara bersama-sama dengan hasil belajar IPA para siswa Sekolah Dasar di Gugus IV Gunung Sari Kecamatan Pamijahan-Bogor

\section{TINJAUAN TEORI}

\subsection{Kerangka Teoritik}

\subsubsection{Hakikat Hasil Belajar Ilmu Pengetahuan Alam}

\section{Pengertian IImu Pengetahuan Alam}

IImu Pengetahuan Alam (IPA) adalah suatu ilmu yang mempelajari tentang alam sekitar beserta isinya. Hal ini berarti IPA mempelajari semua benda yang ada di alam, peristiwa, dan gejala-gejala yang muncul di alam. IImu dapat diartikan sebagai suatu pengetahuan yang bersifat objektif. Jadi dari sisi istilah IPA adalah suatu pengetahuan yang bersifat objektif tentang alam sekitar beserta isinya.

Istilah IImu Pengetahuan Alam atau IPA dikenal juga dengan istilah sains. Kata sains ini berasal dari bahasa latin yaitu scienta yang berarti "saya tahu". Dalam bahasa Inggris, kata sains berasal dari kata science yang berarti "pengetahuan". Science kemudian berkembang menjadi social science yang dalam bahasa Indonesia dikenal dengan IImu Pengetahuan Sosial (IPS) dan natural science yang dalam bahasa Indonesia dikenal dengan IImu Pengetahuan Alam (IPA). Menurut Mustamar (2008:64), natural science didefinisikan sebagai: systematic and formulated knowledge dealing with material phenomena and based mainly on observation and induction (yang diartikan bahwa ilmu pengetahuan alam didefinisikan sebagai: pengetahuan yang sistematis dan disusun dengan menghubungkan gejala-gejala alam yang bersifat kebendaan dan didasarkan pada hasil pengamatan dan induksi). Sumber lain menyatakan bahwa natural science didefinisikan sebagai piece of theoretical knowladge atau sejenis pengetahuan teoritis (Sumaji, 2008:31).

IPA merupakan cabang pengetahuan yang berawal dari fenomena alam. IPA didefinisikan sebagai sekumpulan pengetahuan tentang objek dan fenomena alam yang diperoleh dari hasil pemikiran dan penyelidikan ilmuwan yang dilakukan dengan keterampilan bereksperimen dengan menggunakan metode ilmiah (Amien, 2004:14). Definisi ini memberi pengertian bahwa IPA merupakan cabang pengetahuan yang dibangun berdasarkan pengamatan dan klasifikasi data, dan biasanya disusun dan diverifikasi dalam hukum-hukum yang bersifat kuantitatif, yang melibatkan aplikasi penalaran matematis dan analisis data terhadap gejalagejala alam.

IPA adalah ilmu yang mempelajari tentang fenomena alam dan segala sesuatu yang ada di alam. IPA mempunyai beberapa pengertian berdasarkan cara pandang ilmuwan bersangkutan mulai dari pengertian IPA itu sendiri, cara berfikir IPA, cara penyelidikann IPA sampai objek kajian IPA. Adapun pengertian IPA menurut Winarsih, sains atau IPA merupakan representasi dari hubungan dinamis yang mencakup tiga faktor utama yaitu the extant body of scientific knowledge, the values of science and the method and procecces of science" yang artinya sains merupakan produk dan proses , serta mengandung nilai-nilai (Anny Winarsih, 2008:22).

IPA adalah hasil interpretasi tentang dunia kealaman. IPA sebagai proses/metode penyelidikan meliputi cara berpikir, sikap dan langkah-langkah kegiatan scientis untuk untuk memperoleh produk-produk IPA, misalnya observasi, pengukuran, merumuskan, menguji hipotesa, mengumpulkan data, bereksperimen dan prediksi (Suparno,2007:29). 
Oleh karena itu IPA harus dipandang sebagai cara berpikir untuk memahami alam, sebagai cara untuk melakukan penyelidikan dan sebagai kumpulan pengetahuan. Hal ini sesuai dengan yang dikemukakan oleh Mustamar (2009:44) "IPA harus dipandang sebagai suatu cara berfikir dalam pencarian tentang pengertian rahasia alam dan sebagai batang tubuh pengetahuan yang dihasilkan dari inquiry".

Berdasarkan pengertian di atas, pada hakikatnya IPA merupakan ilmu pengetahuan tentang gejala alam yang dituangkan berupa fakta, konsep, prinsip dan hukum yang teruji kebenaranya dan melalui suatu rangkaian kegiatan dalam metode ilmiah .

\section{Pengertian Belajar}

Belajar merupakan kegiatan berproses dan merupakan unsur yang sangat fundamental dalam setiap jenjang pendidikan. Dalam keseluruhan proses pendidikan, kegiatan belajar merupakan kegiatan yang paling pokok dan penting dalam keseluruhan proses pendidikan.

Belajar adalah proses atau usaha yang dilakukan tiap individu untuk memperoleh suatu perubahan tingkah laku baik dalam bentuk pengetahuan, keterampilan maupun sikap dan nilai yang positif sebagai pengalaman untuk mendapatkan sejumlah kesan dari bahan yang telah dipelajari. Proses pembelajaran tersebut ada yang dilakukan di sekolah, di rumah, dan di tempat lain seperti di laboratorium, di hutan dan dimana saja. Belajar merupakan tindakan dan perilaku siswa yang kompleks sebagai tindakan, maka belajar hanya dialami oleh siswa sendiri dan akan menjadi penentu terjadinya atau tidak terjadinya proses pembelajaran.

Menurut Vernon S. Gerlach \& Donal P. Ely dalam bukunya teaching \& Media-A systematic Approach dalam Arsyad (2011:3) mengemukakan bahwa "belajar adalah perubahan perilaku, sedangkan perilaku itu adalah tindakan yang dapat diamati. Dengan kata lain perilaku adalah suatu tindakan yang dapat diamati atau hasil diakibatkan oleh beberapa tindakan".
Sedangkan Menurut Gagne dalam Wandi (http://www.whandi.net/2013/ pengertian-belajar-menurut-ahli) belajar didefinisikan sebagai suatu proses dimana suatu organisme berubah perilakunya akibat suatu pengalaman. Slameto (2003:5) menyatakan belajar adalah suatu proses usaha yang dilakukan seseorang untuk memperoleh suatu perubahan tingkah laku yang baru secara keseluruhan, sebagai hasil pengalamannya sendiri dalam interaksi dengan lingkungannya. Lebih lanjut Abdillah dalam Aunurrahman (2009:35) menyimpulkan bahwa belajar adalah suatu usaha sadar yang dilakukan oleh individu dalam perubahan tingkah laku baik melalui latihan dan pengalaman yang menyangkut aspek-aspek kognitif, afektif, dan psikomotorik untuk memperoleh tujuan tertentu.

Dengan demikian dapat disimpulkan belajar adalah perubahan tingkah laku pada individu-individu yang belajar. Perubahan itu tidak hanya berkaitan dengan penambahan ilmu pengetahuan, tetapi juga berbentuk kecakapan, keterampilan dan sikap. Jadi, dapat dikatakan bahwa belajar itu sebagai rangkaian kegiatan jiwa raga yang menuju perkembangan pribadi manusia seutuhnya.

\section{Hasil Belajar Ilmu Pengetahuan Alam (IPA)}

IPA sendiri berasal dari kata sains yang berarti alam. Sains menurut Subiyanto (2008:122) merupakan "pengetahuan hasil kegiatan manusia yang bersifat aktif dan dinamis tiada henti-hentinya serta diperoleh melalui metode tertentu yaitu teratur, sistematis, berobjek, bermetode dan berlaku secara universal".

Menurut Kurikulum Tingkat Satuan Pendidikan (KTSP) bahwa: IPA berhubungan dengan cara mencari tahu tentang alam secara sistematis, sehingga bukan hanya penguasaan kumpulan pengetahuan yang berupa fakta, konsep, atau prinsip saja tetapi juga merupakan suatu proses penemuan (Depdiknas, 2006:3).

Dari pendapat di atas maka dapat disimpulkan bahwa IPA merupakan sekumpulan pengetahuan tentang objek dan fenomena alam yang diperoleh dari hasil 
pemikiran dan penyelidikan ilmuwan yang dilakukan dengan keterampilan bereksperimen dengan menggunakan metode ilmiah. Definisi ini memberi pengertian bahwa IPA merupakan cabang pengetahuan yang dibangun berdasarkan pengamatan dan klasifikasi data, biasanya disusun, diverifikasi dalam hukumhukum yang bersifat kuantitatif, melibatkan aplikasi penalaran matematis dan analisis data terhadap gejala-gejala alam. Dengan demikian, pada hakikatnya IPA meliputi tiga cakupan yaitu IPA sebagai produk, IPA sebagai proses dan IPA sebagai sarana pengembangan sikap ilmiah.

Hakikat IPA sebagai produk meliputi konsep-konsep, prinsip-prinsip, hukum-hukum, dan teori-teori didalam IPA yang merupakan hasil rekaan manusia dalam rangka memahami dan menjelaskan alam bersama dengan berbagai fenomena yang terjadi didalamnya. Produk IPA (konsep, prinsip, hukum dan teori) tidak diperoleh berdasarkan fakta semata, melainkan berdasarkan data yang telah teruji melalui serangkaian eksperimen dan penyelidikan.

Menurut Soehakso, hakikat IPA sebagai proses diwujudkan dengan melaksanakan pembelajaran yang melatih keterampilan proses bagaimana cara produk sains ditemukan. yaitu dengan melakukan observasi, mengukur, memprediksi, mengklasifikasi,membandingkan,

menyimpulkan, merumuskan hipotesis, melakukan eksperimen, menganalisis data, dan mengkomunikasikan hasil penelitian. Dalam pengajaran IPA, aspek proses ini muncul dalam bentuk proses pembelajaran. Ada tidaknya aspek proses ini sangat bergantung pada guru.

Hakikat sikap ilmiah adalah berbagai keyakinan, opini dan nilai-nilai yang harus dipertahankan oleh seorang ilmuwan khususnya ketika mencari atau mengembangkan pengetahuan baru. Menurut Rohadi (2008:21), sikap dapat diklasifikasi ke dalam dua kelompok besar: Pertama, seperangkat sikap yang bila diikuti akan membantu proses pemecahan masalah; dan Kedua, seperangkat sikap tertentu yang merupakan cara memandang dunia serta berguna bagi pengembangan karir di masa yang akan datang.

Pembelajaran IPA di SD akan berhasil dengan baik apabila guru memahami perkembangan intelektual anak usia SD. Usia anak SD berkisar antara 7 tahun sampai dengan 11 tahun. Menurut Piaget perkembangan anak usia SD tersebut termasuk dalam katagori operasional konkrit. Pada usia operasional konkrit dicirikan dengan sistem pemikiran yang didasarkan pada aturan tertentu, hal tersebut dapat diterapkan dalam memecahkan persoalanpersoalan konkrit yang dihadapi. Anak operasional konkrit sangat membutuhkan benda-benda konkrit untuk menolong pengembangan intelektualnya.

Hasil belajar Sains tentu saja harus sesuai dengan tujuan pendidikan Sains yang telah dicantumkan dalam garis-garis besar program pengajaran Sains dan tidak melupakan hakikat Sains itu sendiri. Hasil belajar Sains dikelompokan berdasarkan hakikat Sains itu sendiri yaitu sebagai produk dan proses. Hal ini didasarkan pada pendapat TIM Dosen IPA PGSD UPI (2011:21), yang mengatakan bahwa Sains terbagi atas dua bagian yaitu:

1) the investigation (proses) seperti mengamati, mengklasifikasi, mengukur, meramalkan, dan menyimpulkan.

2) the knowledge (produk) seperti fakta, konsep, prinsip, hukum, dan teori Sains. Dengan demikian, sebagai produk hasil belajar Sains berupa pemahaman terhadap fakta, konsep, prinsip, dan hukum Sains, dan sebagai proses, hasil belajar Sains berupa sikap, nilai, dan keterampilan ilmiah.

Supardi (2008:211) memandang bahwa hasil belajar IPA terdiri dari dua aspek yakni aspek kognitif dan nonkognitif. Aspek kognitif yaitu berkaitan dengan pengetahuan, pemahaman, dan keterampilan intelektual lainnya, sedangkan aspek nonkognitif erat kaitannya dengan sikap, emosi (afektif), serta keterampilan fisik atau kerja otot (psikomotorik). 
Jika ditelaah dari hakikat IPA sendiri, maka hasil belajar IPA dilihat dari segi produk, proses, dan sikap. Segi produk, siswa diharapkan mampu menguasai konsepkonsep IPA. Segi proses, siswa diharapkan memiliki kemampuan untuk mengembangkan pengetahuan, gagasan, dan menerapkan konsep yang diperolehnya untuk menjelaskan. Segi sikap dan nilai siswa diharapkan mempunyai minat untuk mempelajari bendabenda di lingkungannya, bersikap ingin tahu, tekun, kritis, mawas diri, serta bertanggung jawab.

Dari beberapa pendapat di atas mengenai hasil belajar IPA dapat disimpulan bahwa hasil belajar IPA merupakan segenap perubahan tingkah laku yang terjadi pada siswa dalam bidang pengetahuan alam sebagai hasil mengikuti proses pembelajaran IPA. Dalam pembelajaran IPA ada tiga macam hasil belajar yaitu: produk, kinerja (proses), dan sikap ilmiah. Dalam penelitian ini hasil belajar yang dimaksud adalah hasil belajar pada ranah kognitif, yaitu pengetahuan tentang ciri-ciri hewan tumbuhan dan manusia, yang terbagi ke dalam 2 aspek ranah yakni ingatan (C1) dan pemahaman (C2)

Alasan peneliti hanya mengukur hasil belajar kognitif karena dengan pertimbangan bahwa: Aspek psikologis siswa yang terpenting adalah aspek kognitif. Aspek kejiwaan yang berkedudukan pada otak ini dalam prespektif psikologi kognitif, merupakan sumber sekaligus pengendali aspek afektif dan psikomotorik. Tidak seperti organ-organ tubuh lainnya, organ otak sebagai tempat fungsi kognitif bukan hanya menjadi penggerak aktivitas akal pikiran, melainkan juga pengontrol aktivitas perasaan dan perbuatan. Tanpa aspek kognitif, sulit bagi seorang siswa untuk dapat berpikir. Tanpa adanya kemampuan berpikir maka siswa tidak pernah dapat memahami materi-materi yang disajikan dan mengambil pesan-pesan moral yang terkandung dalam materi-materi pelajaran (BPTP Disdik Jabar, 2004: 75).

Aspek kognitif merupakan unsur yang ikut berperan terhadap pengembangan aspek afektif dan psikomotorik anak. Aspek afektif dan psikomotorik dipandang sebagai hasil dari perkembangan dan aktivitas aspek kognitif siswa. Upaya pengembangan fungsi aspek kognitif akan berdampak positif bukan hanya terhadap aspek kognitif sendiri, melainkan juga terhadap ranah afektif dan psikomotorik anak. Oleh karena itu, pada penelitian ini hasil belajar yang diukur hanya dari aspek kognitif meliputi pengetahuan, pemahaman, dan aplikasi konsep-konsep IPA. Hasil belajar kognitif IPA dinyatakan dalam skor tes yang diperoleh dari siswa setelah diadakan perlakuan.

\subsubsection{Persepsi Siswa tentang Pemanfaatan Media Pembelajaran KIT IImu Pengetahuan Alam}

\section{Pengertian Persepsi}

Manusia sejak diciptakan dan dilahirkan lebih sempurna dibandingkan dengan makhluk ciptaan lainnya perbedaan itu tidak hanya dari penampilan fisiknya saja (jasmani) melainkan manusia dibekali dengan akal perasaan dan panca indra. Dengan potensi itulah manusia dapat menangkap rangsangan dan mengenal dunia luar sehingga mampu mengenali dirinya sendiri dan menilai stimulus yang ditangkapnya dan melakukan penyesuaian terhadap keadaan sekitarnya yang mana hal ini berkaitan dengan persepsi (perception).

Sedangkan kemampuan manusia untuk membedakan, mengelompokkan, memfokuskan yang ada dilingkungan sekitar siswa disebut sebagai kemampuan untuk mengorganisasikan pengamatan atau persepsi (http://edukasi.kompasiana.com /2013/09/26/persepsi-593377.html). Persepsi merupakan suatu proses yang didahului oleh penginderaan yaitu merupakan proses yang berwujud diterimanya stimulus oleh individu melalui alat reseptornya. Untuk lebih memahami persepsi berikut adalah beberapa definisi persepsi menurut pakar psikologi antara lain sebagai berikut: (1) Persepsi merupakan penafsiran yang terorganisir terhadap suatu stimulus serta mampu mempengaruhi sikap dan perilaku. Persepsi adalah proses penginterpretasian seseorang terhadap stimulus sensori. Proses sensori tersebut hanya melaporkan lingkungan stimulus. 
Persepsi menerjemahkan pesan sensori dalam bentuk yang dapat dipahami dan dirasakan. Persepsi adalah penelitian bagaimana seseorang mengintegrasikan sensori ke dalan perspect obyek dan bagaimana kita selanjutnya menggunakan perspect itu untuk mengenali dunia (Perspect adalah hasil dari perspectual) (Atkinson, 2007:277). Menurut pendapat Kartini Kartono (2004:77) persepsi adalah pengamatan secara global, belum disertai kesadaran, sedang subyek dan obyeknya belum terbedakan satu dari yang lainnya (baru ada proses memiliki tanggapan).

Sedangkan menurut Bimo Walgito (2004:53) persepsi adalah pengorganisasian, penginterpretasian terhadap stimulus yang diterima oleh organisme atau individu sehingga merupakan aktivitas yang integrated dalam diri. Dan menurut pendapat Jalaluddin Rakhmat (2004:51) persepsi adalah pengalaman tentang obyek, peristiwa atau hubungan-hubungan yang diperoleh dengan menyimpulkan informasi dan menafsirkan pesan.

Dengan demikian dari pengertianpengertian persepsi di atas dapat disimpulkan bahwa persepsi adalah proses pengorganisasian dan proses penafsiran/penginterpretasian seseorang terhadap stimulasi yang dipengaruhi oleh berbagai pengetahuan, keinginan dan pengalaman relevan terhadap stimulasi yang dipengaruhi perilaku manusia dalam menentukan tujuan hidupnya

\section{Pengertian Media Pembelajaran KIT IPA}

Secara umum media pembelajaran adalah alat bantu dalam proses pembelajaran. Sesuatu apapun yang dapat dipergunakan untuk merangsang pikiran, perhatian, perasaan, dan kemampuan atau keterampilan pebelajar tersebut sehingga dapat mendorong terjadinya proses pembelajaran (http://anwarpgmi.blogspot.com/2008/07/kump ulan-tesis.html). Batasan dari media pembelajaran ini cukup luas dan mendalam dengan mencakup pengertian sumber, manusia dan lingkungan serta metode yang dimanfaatkan dari tujuan pembelajaran atau pelatihan tersebut.

Singkatnya pengertian media pembelajaran adalah suatu alat sebagai perantara untuk pemahaman makna dari materi yang disampaikan oleh guru baik berupa media cetak atau pun elektronik. Selain itu media pembelajaran adalah alat untuk memperlancar penerapan komponenkomponen dari sistem pembelajaran, sehingga proses pembelajaran dapat bertahan lama dan efektif, suasana belajarpun akan menjadi menyenangkan

Menurut Dirjen Dikdasmen (2003:201) alat peraga KIT IImu Pengetahuan Alam adalah "kotak yang berisi alat-alat IImu Pengetahuan Alam. seperangkat peralatan IImu Pengetahuan Alam tersebut mengarah pada kegiatan yang berkesinambungan atau berkelanjutan". Peralatan IImu Pengetahuan Alam yang dirancang dan dibuat ini menyerupai rangkaian peralatan uji coba keterampilan proses pada bidang studi IImu Pengetahuan Alam. Sebagai alat yang dirancang dan dibuat secara khusus ini maka dapat diartikan bahwa alat peraga Kit IImu Pengetahuan Alam merupakan suatu sistem yang didesain atau dirancang secara khusus untuk suatu tujuan tertentu

Menurut Alipandie (2008:12) "edia/alat peraga KIT IImu Pengetahuan Alam atau loan boxes merupakan salah satu dari media tiga dimensi". Media tiga dimensi dapat memberi pengalaman yang mendalam dan pemahaman yang lengkap akan benda-benda nyata. Loan boxes adalah kotak yang mempunyai bentuk dan besarnya sesuai dengan keperluan. "Kotak ini diisi dengan item-item yang berhubungan dengan unit pelajaran" (http://cucuzakaryya.files.wordpress.com/2010 /05/45.html).

Dari uraian tentang pengertian KIT IPA di atas dapat disimpulkan bahwa alat peraga KIT IImu Pengetahuan Alam adalah kotak yang berisi seperangkat peralatan yang digunakan sebagai alat peraga dalam pembelajaran IImu Pengetahuan Alam yang 
mempunyai bentuk dan besaran sesuai dengan keperluan

\subsubsection{Hakikat Motivasi Belajar}

\section{Pengertian Motivasi}

Istilah motivasi menunjukkan kepada semua gejala yang terkandung dalam stimulasi tindakan ke arah tujuan tertentu dimana sebelumnya tidak ada gerakan menuju ke arah tujuan tersebut. Motivasi dapat berupa dorongan-dorongan dasar atau internal dan insentif diluar diri individu atau hadiah.

Motivasi menurut Hamalik (2004:173) adalah proses membangkitkan, mempertahankan, dan mengontrol minat minat. Selanjutnya Oemar Hamalik (2004:173) menjelaskan "Motivation is a energy change within the person characterized by offective arousal and anticipatory goal reactions". Motivasi adalah suatu perubahan energi di dalam pribadi seseorang yang ditandai dengan timbulnya afektif dan reaksi untuk mencapai tujuan. Perumusan ini mengandung unsur-unsur yang paling berkaitan sebagai berikut: Motivasi dimulai dari adanya perubahan energi dalam pribadi. Perubahanperubahan dalam motivasi timbul dari perubahan-perubahan tertentu di dalam sistem neurofisiologis dalam organisme manusia, misalnya adanya perubahan dalam sistem pencernaan energi yang tidak diketahui. Motivasi ditandai dengan timbulnya perasaan. Mula-mula merupakan ketegangan psikologis, lalu merupakan suasana emosi. Suasana emosi ini menimbulkan kelakuan yang bermotif.

Motivasi ditandai oleh reaksi-reaksi untuk mencapai tujuan. Pribadi yang bermotivasi mengadakan respons-respons yang tertuju ke arah suatu tujuan. Respons tersebut berfungsi mengurangi ketegangan yang disebabkan oleh perubahan energi dalam dirinya. Setiap respons merupakan suatu langkah ke arah pencapaian tujuan.

Motivasi belajar adalah dorongan internal dan eksternal pada peserta didik yang sedang belajar untuk mengadakan perubahan prilaku. Motivasi belajar adalah proses yang memberi semangat belajar, arah, dan kegigihan prilaku. Artinya, prilaku yang termotivasi adalah prilaku yang penuh energy, terarah dan bertahan lama. Jadi motivasi belajar adalah sesuatu yang mendorong seseorang, baik yang berasal dari dalam individu maupun yang berasal dari luar individu untuk melaksanakan suatu kegiatan yang menghasilkan suatu perubahan tingkah laku, baik dalam bentuk pengetahuan dan keterampilan baru, maupun dalam bentuk sikap dan nilai yang positif.

Secara khusus Hamzah (2000:91) mengemukakan bahwa untuk meningkatkan motivasi seseorang terhadap sesuatu maka dapat ditempuh beberapa cara yaitu: Membangkitkan suatu kebutuhan, misalnya kebutuhan untuk menghargai keindahan, untuk mendapatkan penghargaan dan sebagainya, menghubungkan dengan pengalaman-pengalaman yang lampau, dan memberikan kesempatan untuk mendapatkan hasil yang baik.

Seseorang memiliki motivasi yang kuat terhadap sesuatu dipengaruhi oleh adanya kebutuhan seseorang terhadap rasa keindahan, kepuasan, dan untuk mendapatkan penghargaan dari apa yang telah dilakukannya. Semakin tinggi motivasi seseorang terhadap sesuatu akan semakin besar pula motivasi seseorang untuk menghasilkan sesuatu yang dapat memuaskan dirinya. Demikian halnya jika seorang siswa jika merasa dihargai, dihormati dan mendapatkan manfaat jika memperoleh pendidikan maka akan semakin tinggi pula motivasinya untuk mempertinggi prestasi yang diperolehnya

Dari uraian yang tersebut di atas, dapat disimpulkan bahwa pengertian motivasi belajar adalah keseluruhan daya penggerak baik dari dalam diri maupun dari luar siswa (dengan menciptakan serangkaian usaha untuk menyediakan kondisi-kondisi tertentu) yang menjamin kelangsungan dan memberikan arah pada proses pembelajaran dengan indikator: 1) kerja keras, 2) tidak suka santai, 3) tidak suka ketidakefektifan, 4) ada umpan balik (fedback), sehingga tujuan yang dikehendaki oleh subjek belajar itu dapat tercapai. 


\subsection{Hipotesis Penelitian}

Berdasarkan kerangka teori, perumusan masalah dan kerangka berpikir, maka hipotesis dalam penelitian ini dirumuskan sebagai berikut:

1. Terdapat hubungan yang positif antara persepsi siswa tentang pemanfaatan media pembelajaran KIT IPA dengan hasil belajar IPA.

2. Terdapat hubungan yang positif antara motivasi belajar dengan hasil belajar IPA.

3. Terdapat hubungan yang positif antara persepsi siswa tentang pemanfaatan media pembelajaran KIT IPA dan motivasi belajar secara bersama-sama dengan hasil belajar IPA.

\section{METODOLOGI PENELITIAN}

\subsection{Waktu dan Tempat Penelitian}

Penelitian ini dilakukan di Sekolah Dasar yang ada di Gugus IV Gunung Sari Kecamatan Pamijahan-Bogor. Waktu penelitian dimulai dari bulan Desember 2013 s/d April 2014.

\subsection{Metode Penelitian}

Metode penelitian yang digunakan adalah metode survey dengan analisis korelasional. Metode survey adalah penelitian yang dilakukan pada populasi tetapi data yang dipelajari adalah data sampel yang diambil dari populasi. Sedangkan penelitian dengan pendekatan korelasi bertujuan menguji hipotesis yang menyatakan adanya hubungan antara variabel bebas dengan variabel terikat.

\subsection{Populasi dan Sampel Penelitian}

\subsubsection{Populasi Penelitian}

Populasi penelitian ini adalah seluruh siswa kelas VI Sekolah Dasar yang ada di Gugus IV Gunung Sari Kecamatan PamijahanBogor berjumlah 193.

\subsubsection{Sampel Penelitian}

Sampel adalah sebagian atau wakil populasi yang diteliti. Dari populasi sebanyak 193 orang siswa, kemudian ditetapkan sampel penelitian. Teknik penarikan sampel dalam penelitian ini menggunakan rumus penarikan sampel dari Slovin, yakni:

\[ \mathrm{n}=\frac{\mathrm{N}}{\mathrm{N}(\mathrm{d})^{2}+1} \]
$\begin{aligned} & \text { Keterangan: } \\ & \mathrm{n}=\text { sampel }\end{aligned}$
$\mathrm{N}=$ populasi
$\mathrm{d}=$ nilai presisi $5 \%$

Adapun langkah-langkah penentuan sampel sebagai berikut: Dari jumlah populasi sebanyak 193 orang, maka jumlah sampel yang akan digunakan dalam penelitian ini adalah:

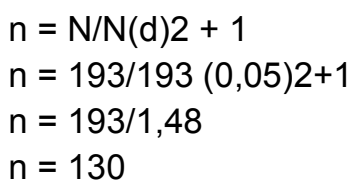

Dari hasil perhitungan, ditetapkan 130 orang sebagai sampel penelitian. Pengambilan 130 orang sampel penelitian menggunakan teknik proposional random sampling, dengan cara diundi, yaitu diambil sebanyak $70 \%$ dari setiap perwakilaan siswa kelas VI di setiap sekolah. Dengan demikian secara keseluruhan jumlah sampel yang diambil sebanyak 130 orang siswa.

\subsection{Instrumen Penelitian}

Untuk memperoleh data tentang ketiga varibel maka disusun instrumen penelitian melalui beberapa tahap yaitu:1) mengkaji semua teori yang berkaitan dengan variabelvariabel penelitian, 2) menyusun indikator dari setiap variabel penelitian, 3) menyusun kisikisi, 4) menyusun butir-butir pernyataan dan menetapkan skala pengukuran, 5) uji coba instrumen, 6) analisis butir soal dengan menguji validitas dan reliabilitas setiap butir soal. Instrumen penelitian dalam bentuk kuesioner terdiri dari: 1) kuesioner persepsi siswa tentang pemanfaatan media pembelajaran KIT IPA, 2) kuesioner motivasi belajar.

\subsection{Teknik Analisa Data}

\subsubsection{Uji Hipotesis}

\section{Uji Korelasi Sederhana}

Teknik korelasi sederhana yang digunakan dalam peneitian ini adalah Product Moment. Hal ini dimaksudkan untuk melihat hubungan antara variabel dalam penelitian. Korelasi sederhana ini untuk menguji hipotesis 
pertama dan hipotesis kedua dengan tingkat kepercayaan (signifikansi) 95\% $(0,05)$.

\section{Uji Korelasi Ganda.}

Uji ini dimaksudkan untuk menguji hipotesis ketiga, yang bertujuan untuk melihat apakah terdapat korelasi yang berarti apabila kedua variabel bebas secara bersama-sama dikorelasikan dengan variabel terikat dengan tingkat kepercayaan (signifikansi) 95\% $(0,05)$.

\section{Uji Korelasi Parsial}

Uji Korelasi Parsial digunakan untuk mengetahui hubungan antara satu variabel bebas dengan variabel terikat dan sebaliknya, jika variabel bebas lainnya dikendalikan atau dijaga tetap (tidak berubah)

\section{HASIL DAN PEMBAHASAN}

\subsection{Hubungan Persepsi Siswa tentang pemanfaatan Media Pembelajaran KIT IPA dengan Hasil Belajar IPA}

Hipotesis pertama yang diajukan dalam penelitian ini adalah terdapat hubungan positif antara persepsi siswa tentang pemanfaatan media pembelajaran KIT IPA (X1) dengan hasil belajar IPA $(\mathrm{Y})$.

Analisis linier sederhana antara persepsi siswa tentang pemanfaatan media pembelajaran KIT IPA (X1) dengan hasil belajar IPA $(Y)$. memiliki persamaan regresi $\hat{Y}$ $=3,304+0,221 \mathrm{X} 1$ dengan koefisien regresi sebesar 0,221 dan konstanta sebesar 3,304.

Pengujian mengenai kebenaran hasil regresi tersebut, juga dimaksudkan untuk menguji hipotesis tentang adanya hubungan positif antara persepsi siswa tentang pemanfaatan media pembelajaran KIT IPA (X1) dengan hasil belajar IPA (Y), maka untuk keperluan itu diperlukan uji signifikasi dan linier terhadap persamaan regresi dengan menggunakan uji $\mathrm{F}$.

Berdasarkan hasil uji keberartian persamaan regresi diperoleh Fhitung sebesar 87,842 sedangkan Ftabel untuk penyebut 1 dan pembilang $128(1 / 128)$ adalah sebesar 3,92 , yang berarti nilai Fhitung > Ftabel. Hal tersebut menunjukkan bahwa hubungan antara variabel persepsi siswa tentang pemanfaatan media pembelajaran KIT IPA
(X1) dengan hasil belajar IPA (Y), adalah sangat signifikan.

Uji linieritas dengan uji $F$ dilakukan untuk menguji apakah persamaan regresi tersebut linier atau tidak. Persamaan regresi dikatakan linier apabila Fhitung < Ftabel. Berdasarkan hasil perhitungan diperoleh nilai Fhitung sebesar -1,013 sedangkan nilai Ftabel untuk penyebut 1 dan pembilang 29 $(1 / 29)$ adalah sebesar 4,18 , atau nilai Fhitung < Ftabel. $(1,013<4,18)$. Hal ini berarti persamaan regresi $\hat{Y}=3,304+0,221 X 1$ dapat dinyatakan linier dan disimpulkan persamaan regresi tersebut bahwa linier dan sangat signifikan.

Hipotesis yang menyatakan bahwa terdapat hubungan positif antara variabel persepsi siswa tentang pemanfaatan media pembelajaran KIT IPA (X1) dengan hasil belajar IPA (Y) diuji dengan analisis regresi sederhana. Perhitungan analisis regresi sederhana menghasilkan koefisien korelasi ry1 sebesar 0,638. Uji keberartian koefisien korelasi dengan uji t. Dari hasil perhitungan diperoleh $\mathrm{t}$ hitung sebesar 9,372 . Sedangkan $\mathrm{t}$ tabel pada taraf kepercayaan $\alpha=0,05$ dengan $\mathrm{dk}=128$ adalah sebesar 1,978 .

Berdasarkan hasil pengujian signifikansi korelasi menunjukkan bahwa $t$ hitung $>t$ tabel $(9,372>1,978)$ Dengan demikian hipotesis penelitian yang menyatakan terdapat hubungan positif antara persepsi siswa tentang pemanfaatan media pembelajaran KIT IPA (X1) dengan hasil belajar IPA (Y), teruji kebenarnnya. Dengan kata lain semakin tinggi persepsi siswa tentang pemanfaatan media pembelajaran KIT IPA (X1) maka akan semakin tinggi juga hasil belajar IPA (Y).

Koefisien determinan (r2y1) sebesar 0,407 yang berarti faktor persepsi siswa tentang pemanfaatan media pembelajaran KIT IPA (X1) berperan atau memberikan kontribusi sebesar 40,7\% terhadap hasil belajar IPA (Y) sedangkan sisanya 59,3\% dipengaruhi oleh faktor lain.

Hasil perhitungan korelasi antara $X_{1}$ dengan $Y$ diperoleh koefisien korelasi sebesar 
$r_{\mathrm{y} .1}=0,691$ sedangkan hasil perhitungan uji korelasi parsial dengan pengendali $\mathrm{X}_{2}$ diperoleh $r_{y .1}=0,448$ dengan nilai uji signifikansi $t_{\text {hitung }}>t_{\text {tabel }}(9,69>1,97)$ pada $\alpha=$ 0,05 . Hal ini berarti bahwa hubungan antara persepsi siswa tentang pemanfaatan media pembelajaran KIT IPA $\left(X_{1}\right)$ dan hasil belajar IPA $(Y)$ tetap signifikan apabila dikontrol oleh variabel motivasi belajar siswa $\left(\mathrm{X}_{2}\right)$, dengan kata lain hubungan antara persepsi siswa tentang pemanfaatan media pembelajaran KIT IPA $\left(\mathrm{X}_{1}\right)$ dan hasil belajar IPA (Y) tidak dipengaruhi secara signifikan oleh motivasi belajar siswa $\left(\mathrm{X}_{2}\right)$

\subsection{Hubungan Motivasi Belajar Siswa dengan Hasil Belajar IPA}

Hipotesis pertama yang diajukan dalam penelitian ini adalah terdapat hubungan positif antara motivasi belajar siswa (X2) dengan hasil belajar IPA (Y).

Analisis linier sederhana antara motivasi belajar siswa (X2) dengan hasil belajar IPA (Y). memiliki persamaan regresi $\hat{Y}=0,977+$ $0,204 X 2$ dengan koefisien regresi sebesar 0,204 dan konstanta sebesar 0,977.

Pengujian mengenai kebenaran hasil regresi tersebut, juga dimaksudkan untuk menguji hipotesis tentang adanya hubungan positif antara motivasi belajar siswa (X2) dengan hasil belajar IPA (Y), maka untuk keperluan itu diperlukan uji signifikasi dan linier terhadap persamaan regresi dengan menggunakan uji $\mathrm{F}$.

Berdasarkan hasil uji keberartian persamaan regresi diperoleh Fhitung sebesar 77,373 sedangkan Ftabel untuk penyebut 1 dan pembilang $128(1 / 128)$ adalah sebesar 3,92, yang berarti nilai Fhitung > Ftabel. Hal tersebut menunjukkan bahwa hubungan antara motivasi belajar siswa (X2) dengan hasil belajar IPA (Y), adalah sangat signifikan.

Uji linieritas dengan uji $F$ dilakukan untuk menguji apakah persamaan regresi tersebut linier atau tidak. Persamaan regresi dikatakan linier apabila Fhitung < Ftabel. Berdasarkan hasil perhitungan diperoleh nilai Fhitung sebesar $-0,598$ sedangkan nilai Ftabel untuk penyebut 1 dan pembilang 28
$(1 / 28)$ adalah sebesar 4,20 , atau nilai Fhitung < Ftabel. $(0,598<4,20)$. Hal ini berarti persamaan regresi $\hat{Y}=0,977+0,204 X 2$ dapat dinyatakan linier dan disimpulkan persamaan regresi tersebut adalah linier dan sangat signifikan.

Hipotesis yang menyatakan bahwa terdapat hubungan positif antara variabel motivasi belajar siswa (X2) dengan hasil belajar IPA $(Y)$ diuji dengan analisis regresi sederhana. Perhitungan analisis regresi sederhana menghasilkan koefisien korelasi ry1 sebesar 0,614. Uji keberartian koefisien korelasi dengan uji t. Dari hasil perhitungan diperoleh $\mathrm{t}$ hitung sebesar 8,796 . Sedangkan $\mathrm{t}$ tabel pada taraf kepercayaan $\alpha=0,05$ dengan $\mathrm{dk}=128$ adalah sebesar 1,978 .

Berdasarkan hasil pengujian signifikansi korelasi menunjukkan bahwa $\mathrm{t}$ hitung $>\mathrm{t}$ tabel $(8,796>1,978)$ Dengan demikian hipotesis penelitian yang menyatakan terdapat hubungan positif antara motivasi belajar siswa (X2) dengan hasil belajar IPA (Y) teruji kebenarnnya. Dengan kata lain semakin tinggi motivasi belajar siswa (X2) maka akan semakin tinggi juga hasil belajar IPA (Y).

Koefisien determinan (r2y1) sebesar 0,377 yang berarti faktor motivasi belajar siswa (X2) berperan atau memberikan kontribusi sebesar $37,7 \%$ terhadap hasil belajar IPA (Y) sedangkan sisanya $62,3 \%$ dipengaruhi oleh faktor lain.

Berdasarkan hasil perhitungan korelasi antara $\mathrm{X}_{2}$ dengan $\mathrm{Y}$ diperoleh koefisien korelasi sebesar $r_{y .2}=0,614$ sedangkan perhitungan uji korelasi parsial dengan pengendali $X_{1}$ diperoleh $r_{y .2}=0,476$ dengan nilai uji signifikansi $t_{\text {hitung }}>t_{\text {tabel }}(9,00>1,97)$ pada $\alpha=0,05$. Hal ini berarti bahwa hubungan antara motivasi belajar siswa $\left(X_{2}\right)$ dan hasil belajar IPA $(Y)$ tetap signifikan apabila dikontrol oleh variabel persepsi siswa tentang pemanfaatan media pembelajaran KIT IPA $\left(X_{1}\right)$, dengan kata lain hubungan antara motivasi belajar siswa $\left(X_{2}\right)$ dengan hasil belajar IPA (Y) tidak dipengaruhi secara signifikan oleh persepsi siswa tentang 
pemanfaatan media pembelajaran KIT IPA $\left(\mathrm{X}_{1}\right)$.

\subsection{Hubungan antara Pemanfaatan Media Pembelajaran KIT IPA dan Motivasi belajar Secara Bersama-sama dengan Hasil belajar IPA}

Hipotesis ketiga yang diajukan dalam penelitian ini adalah terdapat hubungan positif antara persepsi siswa tentang pemanfaatan media pembelajaran KIT IPA (X1) dan motivasi belajar siswa (X2) secara bersamasama dengan hasil belajar IPA (Y). Analisis linier ganda antara persepsi siswa tentang pemanfaatan media pembelajaran KIT IPA dan motivasi belajar siswa secara bersamasama dengan hasil belajar IPA memiliki persamaan regresi $\hat{Y}=9,303+0,157 X 1+$ 0,136X2 dengan koefisien regresi a1 sebesar 0,157 , a2 sebesar 0,136 dan konstanta sebesar 9,303.

Pengujian mengenai kebenaran hasil regresi tersebut, juga dimaksudkan untuk menguji hipotesis tentang adanya hubungan positif antara persepsi siswa tentang pemanfaatan media pembelajaran KIT IPA (X1) dan motivasi belajar siswa (X2) secara bersama-sama dengan hasil belajar IPA $(Y)$, maka diperlukan uji signifikasi dan linier terhadap persamaan regresi dengan menggunakan uji F.

Berdasarkan hasil uji keberartian persamaan regresi linier ganda diperoleh Fhitung sebesar 74,949 sedangkan Ftabel untuk penyebut 2 dan pembilang 127 untuk taraf kepercayaan $\alpha=0,05$ sebesar 3,07 yang berarti nilai Fhitung $>$ Ftabel. Hal tersebut menunjukkan bahwa Ho ditolak, artinya $\mathrm{Ha}$ yang menyatakan terdapat hubungan positif antara persepsi siswa tentang pemanfaatan media pembelajaran KIT IPA (X1) dan motivasi belajar siswa (X2) secara bersamasama dengan hasil belajar IPA $(Y)$ dapat diterima.

\footnotetext{
Hubungan antara variabel persepsi siswa tentang pemanfaatan media pembelajaran KIT IPA (X1) dan motivasi belajar siswa (X2) secara bersama-sama dengan hasil belajar IPA $(Y)$, diperoleh ry.12 sebesar 0,736 yang berarti hubungan antara persepsi siswa tentang pemanfaatan media
}

pembelajaran KIT IPA (X1) dan motivasi belajar siswa (X2) secara bersama-sama dengan hasil belajar IPA (Y) termasuk dalam ketegori kuat/tinggi.

Nilai koefisien determinan (r2y.12) sebesar 0,541 yang berarti faktor persepsi siswa tentang pemanfaatan media pembelajaran KIT IPA (X1) dan motivasi belajar siswa (X2) secara bersama-sama berperan/memberikan kontribusi sebesar $54,1 \%$ terhadap hasil belajar IPA $(Y)$.

Berdasarkan hasil perhitungan diperoleh nilai rhitung $=0,736>$ rtabel $=0,172$ dan Fhitung $=74,949>$ Ftabel $=3,07$. Hal ini berarti bahwa koefisien korelasi antara persepsi siswa tentang pemanfaatan media pembelajaran KIT IPA (X1) dan motivasi belajar siswa (X2) secara bersama-sama dengan hasil belajar IPA (Y) adalah sangat signifikan. Hipotesis yang menyatakan bahwa terdapat hubungan positif antara persepsi siswa tentang pemanfaatan media pembelajaran KIT IPA (X1) dan motivasi belajar siswa (X2) secara bersama-sama dengan hasil belajar IPA (Y) dapat diterima, artinya makin tinggi persepsi siswa tentang pemanfaatan media pembelajaran KIT IPA (X1) dan motivasi belajar siswa (X2) secara bersama-sama maka akan diikuti makin tinggi dan baik hasil belajar IPA (Y).

\section{KESIMPULAN DAN SARAN}

\subsection{Kesimpulan}

Dari hasil analisis data didapatkan persamaan regresi yang terbentuk sebagai berikut :

1. Terdapat hubungan positif dan sangat signifikan antara persepsi siswa tentang pemanfaatan media pembelajaran KIT IPA (X1) dengan hasil belajar IPA (Y). Kekuatan hubungan antara persepsi siswa tentang media pembelajaran KIT IPA (X1) dengan hasil belajar IPA (Y) ditunjukkan dengan koefisien determinasi yang artinya bahwa persepsi siswa tentang pemanfaatan media pembelajaran KIT IPA (X1) memberikan kontribusi tentang hasil belajar IPA (Y). Hubungan fungsional antara Motivasi 
Kerja Guru dengan Kinerja Guru ditunjukkan oleh persamaan regresi

2. Terdapat hubungan positif dan sangat signifikan antara motivasi belajar siswa (X2) dengan hasil belajar IPA (Y). Kekuatan hubungan antara motivasi belajar siswa (X2) dengan hasil belajar IPA (Y) ditunjukkan dengan koefisien korelasi dan koefisien determinasi mengartikan bahwa motivasi belajar siswa (X2) memberikan kontribusi terhadap hasil belajar IPA (Y). Hubungan fungsional antara motivasi belajar siswa (X2) dengan hasil belajar IPA (Y) ditunjukkan oleh persamaan regresi

3. Terdapat hubungan positif antara persepsi siswa tentang pemanfaatan media pembelajaran KIT IPA (X1) dan motivasi belajar siswa (X2) secara bersama-sama dengan hasil belajar IPA $(Y)$. Keduanya berjalan seiring yang artinya makin tinggi persepsi siswa tentang pemanfaatan media pembelajaran KIT IPA (X1) dan motivasi belajar siswa (X2) secara bersama-sama maka makin tinggi pula hasil belajar IPA (Y). Kadar hubungan keduanya ditunjukkan dengan koefisien korelasi dan koefisien determinasi yang berarti bahwa persepsi siswa tentang pemanfaatan media pembelajaran KIT IPA (X1) dan motivasi belajar siswa (X2) secara bersama-sama mempunyai kontribusi terhadap hasil belajar IPA (Y).

\subsection{Saran}

Berdasarkan kesimpulan di atas, dalam upaya meningkatkan hasil belajar IPA, serta meningkatkan pemahaman siswa terhadap pelajaran IImu Pengetahuan Alam, ada beberapa hal yang perlu disampaikan antara lain:

1. Guru harus membina dan mengembangkan kemampuan menyerap informasi tentang pemanfaatan media pembelajaran KIT IPA, misalnya melalui kegiatan KKG, seminar, dan dari media cetak. Disamping media pembelajaran KIT IPA yang harus dikuasai, juga alat peraga lain yang diperlukan perlu dipersiapkan, karena alat peraga mampu menjembatani pemahaman siswa
2. Bagi siswa, pemanfaatan media pembelajaran KIT IPA dalam pelajaran IImu Pengetahuan Alam yang telah dilaksanakan selama kegiatan penelitian sangat baik, hal ini terbukti dari hasil evaluasi terjadi peningkatan yang cukup tinggi, disamping situasi belajar sangat kondusif, karena pembelajaran dengan memanfaatkan media pembelajaran KIT IPA dapat melibatkan siswa secara utuh, artinya terlibat dari awal sampai akhir pembelajaran.

\section{DAFTAR PUSTAKA}

A.M Sardiman,..Interaksi dan Motivasi Belajar Mengajar.(Jakarta: Grafindo.2006)

Arikunto Suharsimi, Prosedur Penelitian Suatu Pendekatan Praktik (Jakarta:Rineka Cipta,2007)

Arsyad Azar. Media Pembelajaran. (Jakarta: Rajawali Press, 2011)

Atkinson dkk, Pengantar Psikologi Jilid II, (Batam: Intereksa, 2007)

Aunurrahman. Belajar dan Pembelajaran. (Bandung : Penerbit Alfabeta, 2009)

BPTP Disdik Jabar, Pengantar Praktik Penilaian Pembelajaran Sains. (Bandung: Balai Pengembangan Teknologi Pendidikan Disdik Jabar, 2004)

Darsono, dkk. Belajar dan Pembelajaran. (Semarang: IKIP Semarang Press.,2000)

Depdiknas, KTSP IPA, (Jakarta: Depdiknas, 2006)

Dimyati. Belajar dan Pembelajaran.(Jakarta: Depdikbud.2005)

Dirjen Dikdasmen, Manfaat penggunaan Alat Peraga, Jakarta, 2003

Ermansyah Alipandie, Alat Peraga Dalam Proses Belajar Mengajar, Graffindo, Jakarta, 2008.

Hamalik Oemar. 2004 Psykologi Belajar dan Mengajar. Bandung, Tarsito, 
Hamzah. Teori Motivasi dan Pengukurannya: Analisis di bibang Pendidikan. (Jakarta: Bumi Aksara, 2000)

http://cucuzakaryya.files.wordpress.com/2010/ 05/45.html. Diakses pada tagal 7 Nop 2013 Pukul 13.30.

http://anwarpgmi.blogspot.com/2008/07/kump ulan-tesis.html, diunduh tanggal 11 Maret 2014. Pukul 14.30 WIB

http://profil.merdeka.com/indonesia/a/achmaddimyati-n/, diunduh tanggal 11 Maret 2014. Pukul 15.00 WIB

Kartono Kartini, Psikologi Umum, (Bandung: Alumni, 2004)

Moejadi. 1994. Model Pemanfaatan KIT IPA $S D$ yang Efektif Untuk Peningkatan Kualitas Pembelajaran IPA. Jakarta : Lembaga Penelitian IKIP Yogyakarta

Rahmat Jalaluddin, Psikologi Umum, (Bandung: Alumni, 2004)

Rohadi.R. Memberdayakan Anak Melalui Pendidikan Sains. Dalam buku kumpulan tulisan, Pendidikan Sains yang Humanistis. (Yogyakarta: Kanisius, 2008)

Rohani Ahmad, Pengelolaan Pengajaran, Rineka Cipata, Jakarta, 2004

Sarwono Sarlito Wirawan, Pengantar Psikologi, (Jakarta: Bulan Bintang, 2006)

Slameto. Belajar dan Faktor-Faktor yang Mempengaruhinya. (Jakarta: PT. Rineka Cipta.2003)

Subiyanto, Pendidikan IImu Pengetahuan Alam. (Jakarta: Depdikbud, 2008)

Sudjana, Metode Statistika, (Bandung : Tarsito,2006)

Supardi, Pendidikan IPA di SD Beserta Cara Pengajarannya, ( Jakarta: Bumi Aksara, 2008)

Tim Dosen Pendidikan IPA PGSD UPP3 FIP. Teori Pembelajaran IPA untuk Sekolah Dasar. (Bandung: UPI, 2011)

Tim SEQIP, Buku IPA Guru Kelas 4, Departemen Pendidikan Nasional, Jakarta, 2003
Usman M.Uzer, Menjadi Guru Profesional. (Bandung: PT Remaja osdakarya.2010)

Walgito Bimo, Pengantar Psikologi Umum, (Yogyagkarta: Andi Offset, 2004)

Wandi, (2007). Pengertian Belajar Menurut Ahli. (Online). http:// www.whandi.net/2013/pengertianbelajar-menurut-ahli. Diakses 21 Oktober 2013 